\title{
Do Marco Polo argali Ovis ammon polii persist in Pakistan?
}

\author{
Hussain Ali, Muhammad Younus, Jaffar Ud Din \\ Richard Bischof and Muhammad Ali Nawaz
}

\begin{abstract}
The distribution range of the Near Threatened Marco Polo argali, or Marco Polo sheep, Ovis ammon polii is restricted to the Pamir Mountains, spanning Afghanistan, Tajikistan, China and Pakistan. Until the early 1970 s the Marco Polo argali was abundant in northern areas of Pakistan, particularly in the Khunjerab and Misgar Valleys around the Pamir Knot, bordering China, Afghanistan and Tajikistan. In Pakistan the subspecies now occurs only in one small watershed, in Khunjerab National Park, bordering China, which it visits sporadically during summer. We used map-based questionnaire surveys, double-observer surveys and camera trapping in a search for Marco Polo argali in the Pakistani Pamirs. We observed a herd of 19 individuals in Karachanai Nallah, in Khunjerab National Park, in 2012. The population that was formerly present in the Misgar Valley appears to have been extirpated, presumably as a result of anthropogenic factors such as poaching, competition with livestock, habitat disturbance, and the construction of a fence along the international border with China. Transboundary migration and range expansion into Pakistan could be facilitated by removal of the border fence adjacent to the Kilik-Mintika area and by limiting livestock grazing in former lambing areas.
\end{abstract}

Keywords Anthropogenic effects, China, fencing, Marco Polo sheep, Ovis ammon polii, Pakistan, poaching, transboundary wildlife

The argali Ovis ammon is categorized as Near - Threatened on the IUCN Red List (Harris \& Reading, 2008) but the Marco Polo argali (or Marco Polo sheep) Ovis ammon polii has not been assessed separately as a subspecies. However, a national assessment categorized the Marco Polo argali as Critically Endangered in Pakistan (Sheikh \& Molur, 2004). The historical distribution of the subspecies includes Pakistan and other countries that share the Pamir Mountains (Russia, Afghanistan, China,

Hussain Ali and Muhammad Ali Nawaz (Corresponding author) Department of Animal Sciences, Quaid-I-Azam University, Islamabad, Pakistan Email nawazma@gmail.com

Muhammad Younus and Jaffar Ud Din Snow Leopard Foundation-Pakistan, Islamabad, Pakistan

RichaRd Bischof Faculty of Environmental Sciences and Natural Resource Management, Norwegian University of Life Sciences, Ås, Norway

Received 12 July 2016. Revision requested 18 October 2016.

Accepted 25 January 2017. First published online 12 April 2017.
Tajikistan and Kyrgyzstan; Heptner et al., 1966; Schaller, 1976, 1977; Petocz et al., 1978; Schaller et al., 1987; Fedosenko, 2000; Habib, 2006; Schaller \& Kang, 2008). Throughout its range it is restricted to sparsely vegetated high-altitude environments (4,500-6,100 m) with harsh climatic conditions (Schaller et al., 1987; Roberts, 1997).

In Pakistan, the Marco Polo argali was reported historically from only three sites in the extreme north-west of Hunza District in Gilgit-Baltistan (Schaller, 1977; Hess et al., 1997; Roberts, 1997); retrospective studies have shown that these valleys were once home to sizeable populations. Roberts (1997) quoted the Mir of Hunza's estimate of 1,00o Marco Polo argali in Khunjerab National Park. Clark (1964) reported the sighting of 65 male Marco Polo argali by an American tourist. Rasool (1981) reported populations of 300, 120, 160 and 100 in 1975, 1976, 1979 and 1980, respectively, but during December 1987-January 1988 the population was estimated to comprise only 20-25 individuals (Rasool, 1990). Ahmad (1996) reported 52 individuals from Karachanai Valley, and Shafiq \& Ali (1998) reported 87 in Khunjerab National Park. Schaller et al. (1987) confirmed local extirpation on the Chinese side of the Khunjerab Pass and referred to the population in the Karachanai area as an isolated one. Schaller et al. (1987) found only a skull as evidence of the Marco Polo argali at the Kilik Pass on the Pakistani side in 1974 but observed 48 individuals on the Chinese side of the Mintika Pass.

Rasool (1990) linked the historical abundance of argali in Pakistan to the ban on hunting imposed by Mir Muhammad Nazim Khan of Hunza (1892-1935), with rampant poaching on the Chinese side forcing the species to take refuge in the Kilik, Mintika and Khunjerab Pass areas until 1949, when the Chinese government imposed a ban on the hunting of argali. Meanwhile the situation reversed in Pakistan following the death of Mir Nazim Khan, and the Mirs and local poachers began hunting the species. The situation worsened during the construction of the Karakoram Highway during the 196os and 1970s, when argali were poached to feed labourers. Observing the species' plight in 1975, George Schaller suggested that the government of Pakistan declare Khunjerab a protected area (Rasool, 1990).

Khunjerab National Park was established in 1975, with the primary objective of protecting remnant populations of Marco Polo argali. However, no agency has monitored the argali population since 1998, and its current status in Khunjerab and other parts of its historical range in Pakistan is unclear. Our study was motivated by this paucity of information about the species' current status in Pakistan. 


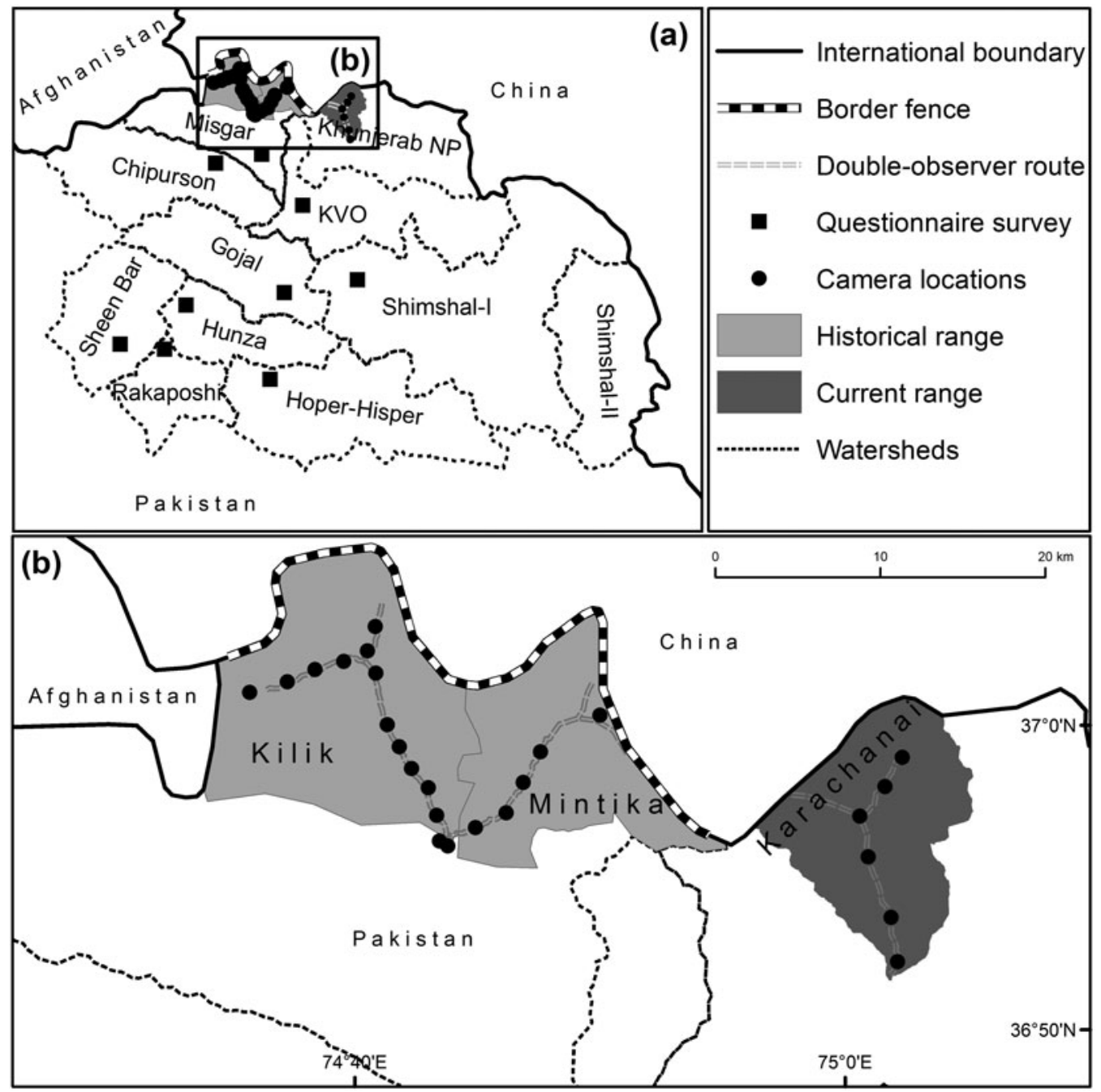

Fig. 1 (a) Watersheds in the Hunza and Nagar Districts of Pakistan where local people participated in a questionnaire survey on the presence/absence of the Marco Polo argali Ovis ammon polii. (b) Locations of camera traps, and the routes of double-observer surveys.

We used three methods: (1) questionnaires to assess the species' status and guide subsequent field surveys; (2) doubleobserver surveys (Suryawanshi et al., 2012; Tumursukh et al., 2016) to estimate abundance, corrected for imperfect detection; and (3) camera trapping (Zaumyslova \& Bondarchuk, 2015) for Marco Polo argali in historically occupied habitat in Hunza District. We also used questionnaires to identify potential factors responsible for local extinctions, and to delineate areas of potential occurrence of the species (Lee et al., 2006).

Local knowledge can yield valuable insights into the status and ecology of wildlife (Gandiwa, 2012). For this reason, and to guide subsequent field surveys, in the first phase questionnaire surveys were undertaken during 19-23 March 2012. The Hunza and Nagar Districts were divided into 11 watershed-based valleys (Fig. 1); 50 interviews targeting local hunters, herders and merchants were conducted in each of nine watersheds (KNP and Shimshal-II were excluded because they had no settlements), to record any sightings during the previous 10 years. Reported observations helped guide the delineation of areas for the cameratrap and double-observer surveys.

Argali presence was reported only by interviewees in the Khunjerab area. The most recent sighting reported by interviewees in Misgar Valley was from c. 2004. Double-observer surveys (Suryawanshi et al., 2012; Tumursukh et al., 2016) were conducted in the second phase of the study, during 25 June-13 July 2012, in the Misgar Valley $\left(956.11 \mathrm{~km}^{2}\right)$ and Khunjerab National Park $\left(1,178.87 \mathrm{~km}^{2}\right)$ areas. These areas were divided into smaller blocks, based on watersheds. In Misgar the surveys focused on Kilik $\left(207 \mathrm{~km}^{2}\right)$ and Mintika $\left(120 \mathrm{~km}^{2}\right)$, and in Khunjerab National Park surveys were conducted in Karachanai $\left(78.3 \mathrm{~km}^{2}\right)$ (Fig. 1). Two observers separated by time ( 15 minutes), if only one trail was available, and space, if two trails were available, surveyed each watershed by walking along pre-determined routes (Fig. 1). Both observers recorded any pellets, tracks and skulls of argali encountered during the survey. 


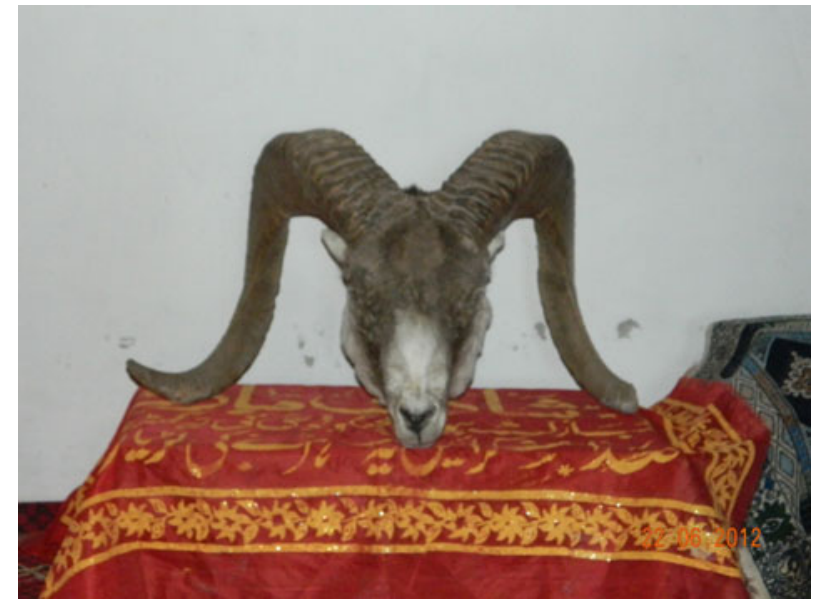

PLATE 1 Skull of a Marco Polo argali Ovis ammon polii ram allegedly poached in 2007 near the Pakistan-Afghanistan border.

The third phase took place during 11 May-17 June 2013. Twenty trail cameras (Reconyx HC 500 and HC 900; Reconyx, Holmen, USA) were installed for 1 month in areas where argali occurrence was reported by local people in the Kilik-Mintika area of Misgar and in Khunjerab National Park (Fig. 1).

In Chipurson Valley, which is contiguous with Misgar Valley and the Wakhan corridor of Afghanistan (Fig. 1a), neither the map-based questionnaire nor the doubleobserver survey yielded evidence of Marco Polo argali. Questionnaire respondents reported argali in the KilikMintika area but this was not confirmed by the doubleobserver survey. In Chipurson Valley a poacher produced the skull of a male argali, which allegedly had been killed illegally at the Pakistan-Afghanistan border in 2007 (Plate 1). In Karachanai Nallah, Khunjerab National Park, both observers encountered a single herd comprising five males, eight females and six lambs (Plate 2). No Marco Polo argali were photographed by camera traps in either the Misgar Valley or Khunjerab National Park.

Our surveys in Chipurson Valley, Kilik and Mintika found livestock grazing extensively. These areas lie above 4,000 m, and because of the short growing season for grasses and forbs there was considerable competition for resources, even among livestock (authors, pers. obs.). This may have been sufficient for exclusion of wild sheep from the area (Bagchi et al., 2004; Mishra et al., 2004; Schaller \& Kang, 2008; Mallon et al., 2014), even in the absence of poaching. Fencing by the Chinese authorities at Kilik Pass may obstruct potential corridors by which argali could cross into Pakistan (Schaller \& Kang, 2008). Snow-capped moutains hinder argali migration from Wakhjir Valley (Afghanistan) into Pakistan.

Hess et al. (1997) assumed that the extinction of the Marco Polo argali in the Pamir Knot occurred as a result of poaching; however, wildlife authorities did not allow local people to enter Kilik and Mintika prior to 2012.

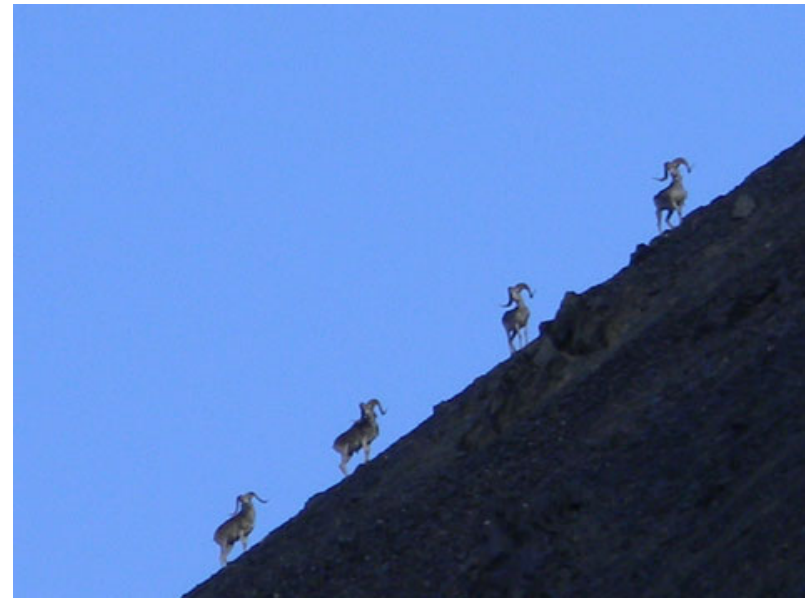

Plate 2 Four rams, part of a herd of 19 individuals, sighted in Karachanai Nallah, Khunjerab National Park (Fig. 1) in 2012.

Local people suggested that the extirpation of the Marco Polo argali in the Kilik-Mintika area was a result of the Chinese fence. Similarly, Fox et al. (2008) and Luikart et al. (2011) cited fencing as a hurdle to the movement of the Tibetan antelope Pantholops hodgsonii in China, and there is increasing awareness of the negative ecological impacts of international border fences elsewhere (Lasky et al., 2011; Linnell et al., 2016).

In 1991, after meeting with the Khunjerab Village Organization, the Khunjerab National Park administration imposed a total ban on livestock grazing in the Walakdur area in Karachanai Nallah (Hess et al., 1997). The movement of Marco Polo argali has increased since then (Riaz \& Akram, 2012, pers. comm.). However, herders and poachers who used to visit Karachanai prior to the establishment of the Park reported that movement and numbers had decreased despite improved monitoring and the livestock grazing ban.

It is likely that livestock grazing and fencing along the international border have had negative effects on the movement and persistence of Marco Polo argali in their historical range in Pakistan. The species now appears to be confined to a single watershed in Khunjerab National Park, which it visits only during the summer. We recommend implementation of more effective monitoring of argali at the Kilik and Mintika game reserves. This could be achieved by recruiting local people as game watchers and involving them in game reserve management planning, as well as convincing them to keep livestock away from core areas of the reserves. We also recommend that government authorities negotiate with their Chinese counterparts for the removal of the fence from the Kilik and Khunjerab passes. Studies to understand resource competition (Namgail, 2006) between the Marco Polo argali and the Himalayan ibex Capra ibex sibirica in Karachanai Nallah are required, as the ibex population is increasing. Cross-border cooperation could also improve the chance of long-term survival of the Marco 
Polo argali in the Pamirs. Such efforts could include joint studies, for example using camera trapping and faecal DNA analysis to monitor space use and migratory movements by transboundary herds. Since the completion of our study the Parks and Wildlife Department in GilgitBaltistan has recruited local guards to protect wildlife in the Kilik-Mintika area but to date the guards have not reported the occurrence of argali there. Neither the Pakistani nor Chinese authorities have initiated discussion regarding the removal of the border fence from the KilikMintika area.

\section{Acknowledgements}

We thank the Parks and Wildlife Department in GilgitBaltistan, the Chipurson Local Support Organization, the Misgar community, and the Wildlife Conservation Society for their support during the field research.

\section{Author contributions}

HA, MAN and JUD conceived and designed the study, with help from RB. HA, JUD and MY collected the data. HA wrote the draft of the article and all authors contributed to subsequent versions.

\section{References}

Ahmad, A. (1996) Management Plan, Khunjerab National Park. WWF-Pakistan, Lahore, Pakistan.

Bagchi, S., Mishra, C. \& Bhatnagar, Y.V. (2004) Conflicts between traditional pastoralism and conservation of Himalayan ibex (Capra sibirica) in the Trans-Himalayan mountains. Animal Conservation, 7, 121-128.

Clark, J. (1964) The Great Arc of Wild Sheep. University of Oklahoma Press, Norman, USA.

Fedosenko, A. (2000) Argali Sheep in Russia and Adjacent Territories. Centre for Hunting Control, Moscow, Russia.

Fox, J.L., Dhondup, K. \& Dorj, T. (2008) Tibetan Antelope and New Rangeland Management Activities in and Around the Aru Basin, Chang Tang Nature Reserve. University of Tromsø, Tromsø, Norway.

Gandiwa, E. (2012) Local knowledge and perceptions of animal population abundances by communities adjacent to the northern Gonarezhou National Park, Zimbabwe. Tropical Conservation Science, 5, 255-269.

НАвı, B. (2006) Status of Large Mammals in Proposed Big Pamir Wildlife Reserve, Wakhan, Afghanistan. WCS, Wakhan, Afghanistan.

Harris, R.B. \& READING, R. (2008) Ovis ammon. The IUCN Red List of Threatened Species 2008: e.T15733A5074694. Http://dx.doi.org/10. 2305/IUCN.UK.2008.RLTS.T15733A5074694.en [accessed 22 February 2017].

Heptner, V., Nasimovic, A. \& Bannikov, A. (1966) Die Sgiugetiere der Sojetunion. Volume I. Gustav Fischer Verlag, Jena, Germany.

Hess, R., Bollmann, K., Rasool, G., Chaudhry, A.A., Virk, A.T. \& Ahmad, A. (1997) Pakistan. In Wild Sheep and Goats and their
Relatives (ed. D.M. Shackleton), pp. 239-26o. IUCN/SSC Caprinae Specialist Group, Gland, Switzerland.

LASKy, J.R., JetZ, W. \& KeitT, T.H. (2011) Conservation biogeography of the US-Mexico border: a transcontinental risk assessment of barriers to animal dispersal. Diversity and Distributions, 17, 673-687.

Lee, T., Quinn, M.S. \& Duke, D. (2006) Citizen, science, highways, and wildlife: using a web-based GIS to engage citizens in collecting wildlife information. Ecology and Society, 11, http://www.

ecologyandsociety.org/voli1/iss1/art11/.

Linnell, J.D.C., Trouwborst, A., Boitani, L., Kaczensky, P., Huber, D., Reljic, S. et al. (2016) Border security fencing and wildlife: the end of the transboundary paradigm in Eurasia? PLoS Biology, 14(6), e1002483.

Luikart, G., Amish, S.J., Winnie, J., Beja-Pereira, A., Godinho, R., Allendorf, F.W. \& Harris, R.B. (2011) High connectivity among argali sheep from Afghanistan and adjacent countries: inferences from neutral and candidate gene microsatellites. Conservation Genetics, 12, 921-931.

Mallon, D., Singh, N. \& Röttger, C. (2014) International Single Species Action Plan for the Conservation of the Argali Ovis ammon. CMS Technical Series No. XX, Bonn, Germany.

Mishra, C., Van Wieren, S.E., Ketner, P., Heitkönig, I.M.A. \& Prins, H.H.T. (2004) Competition between domestic livestock and wild bharal Pseudois nayaur in the Indian Trans-Himalaya. Journal of Applied Ecology, 41, 344-354.

Namgail, T. (2006) Winter habitat partitioning between Asiatic ibex and blue sheep in Ladakh, northern India. Journal of Mountain Ecology, 8, 7-13.

Petocz, R., Habibi, K., Jamil, A. \& Wassey, A. (1978) Report on the Afghan Pamir. Part 2. Biology of Marco Polo Sheep (Ovis ammon polii). UNDP, FAO, Ministry of Agriculture, Kabul, Afghanistan.

Rasool, G. (1981) Khujerab National Park. Natura (WWF Pakistan Newsletter). WWF-Pakistan, Lahore, Pakistan.

Rasool, G. (1990) Population status of wildlife in Khunjerab National Park (Pakistan). Tiger Paper, 14, 25-28.

Roberts, T.J. (1997) Mammals of Pakistan. Oxford University Press, Karachi, Pakistan.

Schaller, G.B. (1976) Mountain mammals in Pakistan. Oryx, 13, 351356.

SCHAller, G.B. (1977) Mountain Monarchs: Wild Sheep and Goats of the Himalaya. University of Chicago Press, Chicago, USA.

Schaller, G.B. \& Kang, A. (2008) Status of Marco Polo sheep Ovis ammon polii in China and adjacent countries: conservation of a Vulnerable subspecies. Oryx, 42, 100-106.

Schaller, G.B., Talipu, L.H., Hua, L., Junrang, R., Mingiang, Q. \& Haibin, W. (1987) Status of large mammals in the Taxkorgan Reserve, Xinjiang, China. Biological Conservation, 42, 53-71.

ShafiQ, M.M. \& Ali, A. (1998) Status of large mammal species in Khunjerab National Park. Pakistan. The Pakistan Journal of Forestry, 48, 1-4.

Sheik, K.M. \& Molur, S. (2004) Status and Red List of Pakistan's Mammals. Based on the conservation assessment and management plan. IUCN Pakistan, Islamabad, Pakistan.

Suryawanshi, K.R., Bhatnagar, Y.V. \& Mishra, C. (2012) Standardizing the double-observer survey method for estimating mountain ungulate prey of the endangered snow leopard. Oecologia, $169,581-590$.

Tumursukh, L., Suryawanshi, K.R., Mishra, C., McCarthy, T.M. \& Boldgiv, B. (2016) Status of the mountain ungulate prey of the Endangered snow leopard Panthera uncia in the Tost Local Protected Area, South Gobi, Mongolia. Oryx, 50, 214-219.

Zaumyslova, O.Y. \& Bondarchuk, S.N. (2015) The use of camera traps for monitoring the population of long-tailed gorals. Achievements in the Life Sciences, 9, 15-21. 


\section{Biographical sketches}

Hussain Ali studies the ecology and conservation of mountain ungulates of Pakistan. Munammad Younus' interests lie in understanding livestock-wildlife disease transmission patterns. JAFFAR UD DIN is interested in carnivore distribution and conservation.
Richard Bischof's work focuses on wildlife management, noninvasive monitoring, and quantitative ecology. Muhammad Ali NAWAZ is interested in molecular and field studies for natural resource management, and has been studying the ecology, co-existence and conservation of carnivores in Pakistan. 